\title{
Climate and Epidemiology of Malaria in Port Harcourt Region, Nigeria
}

\author{
Vincent Ezikornwor Weli1*, Sunday Ighovie Efe ${ }^{2}$ \\ ${ }^{1}$ Department of Geography and Environmental Management, University of Port Harcourt, Port Harcourt, \\ Nigeria \\ ${ }^{2}$ Department of Geography and Regional Panning, Delta State University Abraka, Abraka, Nigeria \\ Email: *welivinezi@yahoo.com, efesundayighovie@gmail.com
}

Received 17 February 2015; accepted 8 March 2015; published 12 March 2015

Copyright (C) 2015 by authors and Scientific Research Publishing Inc.

This work is licensed under the Creative Commons Attribution International License (CC BY).

http://creativecommons.org/licenses/by/4.0/

(c) (;) Open Access

\section{Abstract}

The study examines the effect of climate on the occurrence of malaria in Port Harcourt. To achieve this, the study adopted the survey designs which involved the use of archival data of climate parameters and the survey of hospitals for epidemiological data of malaria cases reports within Port Harcourt and environs. The archival weather data on temperature and rainfall were collected from the Nigeria Meteorological Service Agency (NIMET) for a period of sixty-five (65) years (1950-2014), and those for medical records of malaria cases were extracted from the University of Port Harcourt Teaching Hospitals (UPTH), Braithwaite Memorial Hospital (BMH) and some renowned private hospitals in Port Harcourt and environs for a period of sixty-five (65) years. The multiple regression analysis was used to determine the relative effect of rainfall and temperature on malaria incidence. The polynomial and linear trend analysis was used for the trend pattern of malaria cases, rainfall and temperature. The results revealed an annual rainfall of $2375 \mathrm{~mm}$, with an increase of $1581 \mathrm{~mm}$ of rainfall from 1950 till date. It also showed an urban warming of $3^{\circ} \mathrm{C}$ from 1950 to 2014 , and a mean of $27.2^{\circ} \mathrm{C}$ in temperature in Port Harcourt. The results of the multiple regression reveal that the prevalence of malaria is significantly dependent on the increase in rainfall and temperature in Port Harcourt. There are double maxima of malaria cases with 1006 cases in July and 1540 cases in September, which coincide with the months with double rain maxima. On this premise and health care planning and development, it is recommended that regular clearing of drains and the surrounding environment on monthly basis should be intensified, as well as the distribution of mosquito's insecticide net by the three tier of government.

\section{Keywords}

Malaria, Rainfall, Temperature, Port Harcourt

\footnotetext{
${ }^{*}$ Corresponding author.
} 


\section{Introduction}

Over the years, weather extremities are more intense, more frequent and have impacted negatively on infectious disease as climate changes over the globe [1]-[3]. Malaria is a life-threatening parasitic disease transmitted by female mosquitoes of the genus Anopheles it is endemic in over 100 countries, causing an estimated 900 million clinical cases and almost 3 million deaths annually [4]. A climate variation has direct effect on the epidemiology of many vector borne diseases [5] [6], and one of such diseases is malaria. Malaria is a major public health burden in the tropics, and has the potential to significantly increase in response to climate change [7] [8]. Over the past century the world has warmed by $0.6^{\circ} \mathrm{C}$, with a range of ecological consequences [8] [9]. According to [9] malaria kills over one million people each year, while 300 to 500 million people are suffering from chronic malaria around the world. This is one of the most common and serious diseases of our time. The death toll is predicted to double in the next 20 years if no new control measures are developed [10]. Adding to the scenario are the anthropogenic changes in our environment. Global change inflicted by man in ways of increased emissions of greenhouse gases or disrupted nutrient cycles has been known to cause great ecological responses [11].

The worries have tremendously increased in recent years, partly because of extreme events resulting from climate variation [12]. Incidence of malaria varies with weather, which affects the ability of the main carrier of malaria parasites, anopheline mosquitoes, to survive or otherwise. Tropical areas including Nigeria have the best combination of adequate rainfall, temperature and humidity allowing for breeding and survival of anopheline mosquitoes. The burden of malaria varies across different regions of the world and even within a country [13]. Succinctly, the problems of climatic variation which include flooding, storms, etc., have a marked effect on the prevalence of mosquitoes which cause malaria. The disease, malaria, is a major health problem in Nigeria, with stable transmission throughout the country. It accounts for about $50 \%$ of out-patient consultation, $15 \%$ of hospital admission, and also prime among the top three causes of death in the country National Malaria Control Plan of Action 1996 to 2001 [14]. The trend is rapidly increasing due to the current malaria resistance to first line antimalarial drugs [9]. Indirectly, malaria impairs the ability of people to work hard by losing productive time during care-giving activities, while adults with malaria severely compromise household/family resources, as their capacity to work, earn income and save for their families is reduced. Added to this, the illness generates new financial demands to cover medical treatment and threatening food supply. Furthermore, it affects child's development and compromise future productive capacity due to absenteeism from school associated with malaria attack. Also, malaria is known to be a main cause of anaemia, epileptic convulsions, growth faltering, and neurological squeal [13]. In Port Harcourt and environs, weather and climate tends to affect the spread of malaria. However, there are no demarcated seasons in Port Harcourt because rain tends to fall virtually throughout the year and it has given rise to annual increased precipitation and high temperature [15]. This rate of increased precipitation stimulates breeding sites of mosquito which results to an increased mosquito bite. Due to urbanization process going on in Port Harcourt most of the natural drains has been closed and the constructed drains are blocked with litters of garbage, hence making areas like Okilton Drive, Mgbuogba axis, GRA phase III, Abacha road axis, Ibeto reclamation areas, Bundu squatter areas etc. to experience flood; which in turn results to breeding grounds for mosquitoes [16]. Thus, in the wet seasons, mosquito's larvae development is at maxima because of the increase in precipitation and poor environment management [17]. The residence of Port Harcourt are vulnerable to mosquito bite resulting in malaria because most of the houses are within the fringes of water bodies, farm gardens and tall grasses as well as within flight distance from it respective breeding habitats. Mosquitoes also breed on the edges of ponds and streams, open septic tanks, open cesspools, in salt marshes, overflowing sewages, holes in stumps or trees, water barrels, clogged troughs, street catch basins, empty tin cans and jars. The people tends to suffer from the impact of mosquitoes as a result of its biting and pierce leading to swollen body parts when they are in their houses or comes out at night to receive cool air from their surroundings. It is on this basis that the following questions come to mind as: has there been climate change in Port Harcourt metropolis? Does climate influence the prevalence of malaria? At what period of the year is the effect of climate on malaria disease at its peak? Based on the problems and questions this study is therefore set to examine climate variation and the incidence of malaria in the Port Harcourt metropolis.

\section{The Study Area}

Port Harcourt is the capital of Rivers State. It is the main city in the state and has one of the largest sea port in the Niger Delta region of Nigeria. It is the hub of industrial, commercial, administration and other activities in 
the state. The city lies between latitude $0^{\circ} 23^{\prime}-7^{\circ} 30^{\prime} \mathrm{E}$ and $5^{\circ} 45^{\prime}-40^{\circ} 15^{\prime} \mathrm{N}$. It covers an estimated area of 1811.6 square kilometers. The city is bounded in the north by Imo and Abia States east by Akwa-Ibom State, West by Bayelsa State and south by the Atlantic Ocean. Weather systems particularly rainfall in Nigeria are primarily a result of the interplay between two major pressure and wind systems. These are the two dynamically generated sub-tropical high pressure cells centered over Azores Archipelago (off the west coast of North Africa) and St. Hellena Islands (off the coast of Namibia). These high pressure centers (or anticyclones) which are permanent generate and drive respectively the North-East trade winds and the South-West winds, which are the northward extension of the re-curved South-East trade winds of the South Atlantic Ocean. The major rainfall controls over Nigeria are, apart from the seasonal location of the ITD, the distance inland from the coast and relief. Generally, rainfall over Nigeria diminishes with increasing distance from the moisture source in the South Atlantic. Thus, coastal areas like the Port Harcourt region, receive heavier and more persistent rainfall because the South-West wind is strong. The increased rainfall stimulate stagnant water in within the city that act as breeding grounds for mosquitoes. The strength of the air mass is reduced as it penetrates inland. This also affects temperature. Ascent of air over high ground produces cooling which can lead to condensation and precipitation and it is described as orography rainfall, does not control any weather system in the region in that the area is devoid of any high lands. Pollution in the atmospheric medium travels the farthest and industrial emissions are one of the most important sources of air pollution. The implications of the location pattern of industries for pollution are many. The dominant airmass over Port Harcourt is the South West Trade Wind. Detailed wind flow characteristics over the city include periodic doses of emission from the major industrial locations around the city. The incidence of land breeze, as well as, the Harmattan factor actually transfers emissions into the city [15] [16] [18]. In Port Harcourt and environs, climate tends to affect the spread of malaria. [15] opined that there is no demarcated season in Port Harcourt because rain tends to fall virtually throughout the year and it has given rise to annual increased precipitation and high temperature. This rate of increased precipitation stimulates breeding grounds for mosquito which results to an increased mosquito bite.

\section{Methods of Data Collection}

The study employed the survey designs which involved the use of archival data of climate parameters and epidemiological data of malaria cases reports from Port Harcourt and environs. The data used for this study are archival weather data on temperature and rainfall collected from the Nigeria Meteorological Service Agency (NIMET) for a period of sixty-five (65) years (1950-2014) and medical records of malaria cases from the University of Port Harcourt teaching Hospitals (UPTH), Braithwaite memorial hospital (BMH) and some renowned private hospitals in Port Harcourt and environs for a period of 65 years. Data on malaria cases reported by place of diagnoses were obtained from the two (2) tertiary hospitals (UPTH and BMH) and one (1) renowned hospital each from the three (3) local Government Areas; (Ebony Clinic, Ebony Rd.Oroazi) Obio/Akpo (St. Patrick hospital, Ogbunabali) Port Harcourt; and (Eleme general hospital) Eleme respectively. The choice of these hospitals is based on the fact that data of epidemiological cases are forwarded from the smaller hospitals to the two central hospitals for onward transmission to the state ministry of health, and secondly most of the hospitals/clinics hardly keep records cases treated. As such there are dearth of data from such hospitals and clinics. The medical record contains the number of patients treated for malaria for the period of 1950-2014. The malaria data was extracted from medical records and which contained the malaria in-patient and out-patient cases on yearly and the monthly basis. Temperature and rainfall data for Port Harcourt were retrieved from the climate archival records unit of NIMET Lagos being the sub headquarters in Nigeria. The climate data which contains the mean annual temperatures and rainfall amount were used. Where there are missing data, extrapolation and interpolation methods adopted by [6] [19] [20] was employed. Statistical diagram, polynomial and linear trend analysis and multiple regression analysis were used for the study. The multiple regression analysis was used to determine the relative effect of rainfall and temperature on malaria incidence. The polynomial and linear trend analysis were used for the trend pattern of malaria cases, rainfall and temperature in line with [6] study.

\section{Results and Discussion}

This section presents and discusses the data collected for the study.

Figure 1 showed 1936 mean annual cases of malaria incidence in Port Harcourt, which span 65 cases in 1950 to 8999 cases in 2014; this indicates an increase of 8934 cases from 1950 till date (see Figure 1). The poly- 


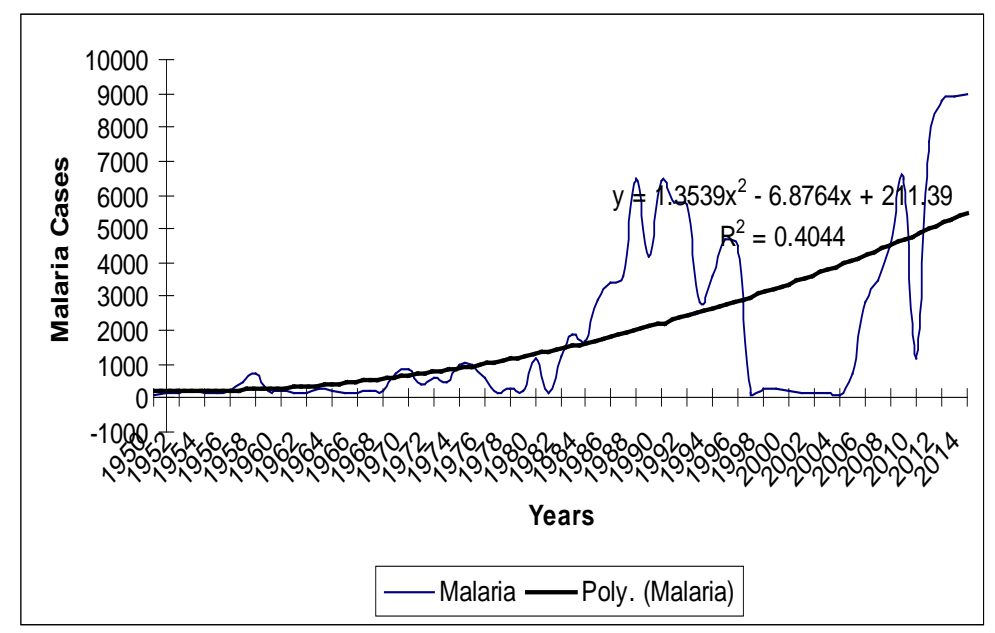

Figure 1. Mean annual pattern of malaria cases.

nomial trendline showed a gradual increase in malaria incidence from 1950 to 2014, with $R^{2}$ value of 0.40 and it indicates a direct relationship with increase in years. This corroborated [6] who demonstrated the ecology of malaria in relation to spatial context in Warri metropolis. The increased in malaria incidence, is activated by increase in rainfall (see Figure 2) that stimulates breeding ground of mosquito prevalence and such results in increased mosquito bite. Also urbanization processes in Port Harcourt have closed most of the natural drains and the constructed drains are blocked with litters of garbage, hence making areas like Okilton Drive, Mgbuogba axis, GRA phase III, Abacha road axis, Ibeto reclamation areas, Bundu squatter areas etc to experience flood hazard; which in turn act as breeding grounds for mosquitoes [16].

From Figure 2 showed an annual mean of $2375 \mathrm{~mm}$ from 1950 to 2014 in rainfall, which range from 1475 $\mathrm{mm}$ in 1951 to $3056 \mathrm{~mm}$ in 2012 (an increase of $1581 \mathrm{~mm}$ ). In Figure 2, rainfall showed a fluctuating pattern from 1950 to 2014 with nine rainfall epochs of $2500 \mathrm{~mm}$ and above. These rainfall epochs are 1955 and 1977 (2772 mm and $2794 \mathrm{~mm}$ ); 1960-1962 (2991 - $3005 \mathrm{~mm}$ ); 1964-1966 (2581 mm - $2971 \mathrm{~mm}$; 1968-1969 (2639 mm - 2525 mm); 1979-1980 (2500 mm - 2545 mm); 1981, 1987 (2531, 2724 mm); 1993-2007 (2560 - 2866 $\mathrm{mm})$; 2003, 2009 (2502 mm, $2564 \mathrm{~mm})$; and 2012-2013/2014 (3045 mm - $3047 \mathrm{~mm}$ and $3003 \mathrm{~mm})$. The linear trend line show an increase in rainfall over the years, with $0.61 \mathrm{R}^{2}$ value and shows an increase of $1581 \mathrm{~mm}$ from 1950-2014. Similarly from Figure 3, Port Harcourt over the years experienced a rise of $3^{\circ} \mathrm{C}$ in temperature $\left(25^{\circ} \mathrm{C}-28^{\circ} \mathrm{C}\right)$ from $1950-2014$, with $27.2^{\circ} \mathrm{C}$ mean annual temperature distribution.

Other years $1951-2013$ had temperature that span $26.1^{\circ} \mathrm{C}-27.9^{\circ} \mathrm{C}$ with a range of $1.8^{\circ} \mathrm{C}$, indicating that recent years are warmer that the first climatic normal. This is evident from the fact that temperature in the first climate normal (1950-1979) span $25^{\circ} \mathrm{C}$ to $27.7^{\circ} \mathrm{C}$; second normal (1980-2009) recorded $26.5^{\circ} \mathrm{C}$ to $27.8^{\circ} \mathrm{C}$, and the last cycle (2010-2014) had $27.6^{\circ} \mathrm{C}$ to $28^{\circ} \mathrm{C}$ (see Figure 3), indicating a rise of $0.1^{\circ} \mathrm{C}$ and $0.2^{\circ} \mathrm{C}$ respectively amongst these cycles. The linear trend line of temperature showed a rise in temperature with $\mathrm{R}^{2}$ value of 0.16 . The flow pattern of rainfall and temperature followed that of malaria incidence in Figure 3, and these corroborated [6] [20]. This shows that when there is an increase in rainfall, there is also an increase in malaria cases in the area.

Table 1 showed the seasonal distribution of malaria cases and climate Characteristics in Port Harcourt. The epidemiology of malaria showed malaria incidence of 482 cases in January to 1540 cases in September, and this indicates double maxima of malaria cases (1006 cases in July and 1540 cases in September) in the area. This pattern followed those of rainfall (see Figure 4).

The climate characteristics showed $196 \mathrm{~mm}$ mean annual rainfall $196 \mathrm{~mm}$, which span $28 \mathrm{~mm}$ in January to $368 \mathrm{~mm}$ in September. Figure 4 and Figure 5 showed that July and September had double rain maxima in Port Harcourt (359 and 368 respectively) with $\mathrm{R}^{2}$ value of 0.85 from the polynomial trend line, and this confirmed the feature of tropical equatorial climate of Koppen [19] (see Figure 5). Port Harcourt had $27.1^{\circ} \mathrm{C}$ monthly mean temperature, and it ranged from $26^{\circ} \mathrm{C}$ in September to $28.6^{\circ} \mathrm{C}$ in March, indicating an increase of $1.5^{\circ} \mathrm{C}$ (see Figure 6).

There is double fall in temperature in the months of July and September in line with double maxima of rain- 


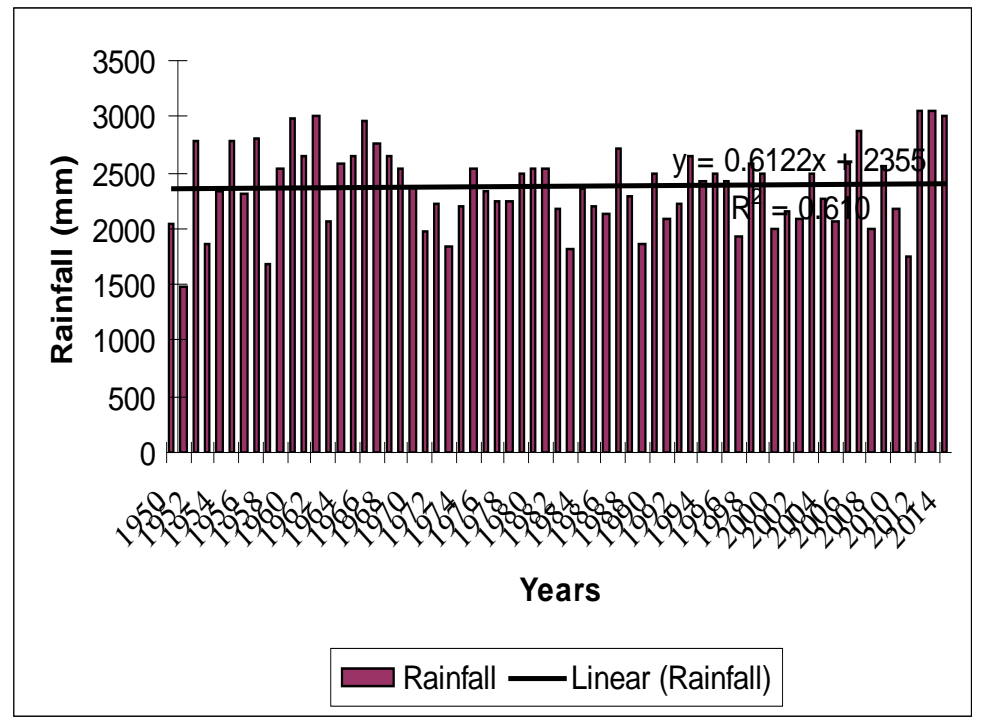

Figure 2. Mean annual distribution of rainfall (1950-2014).

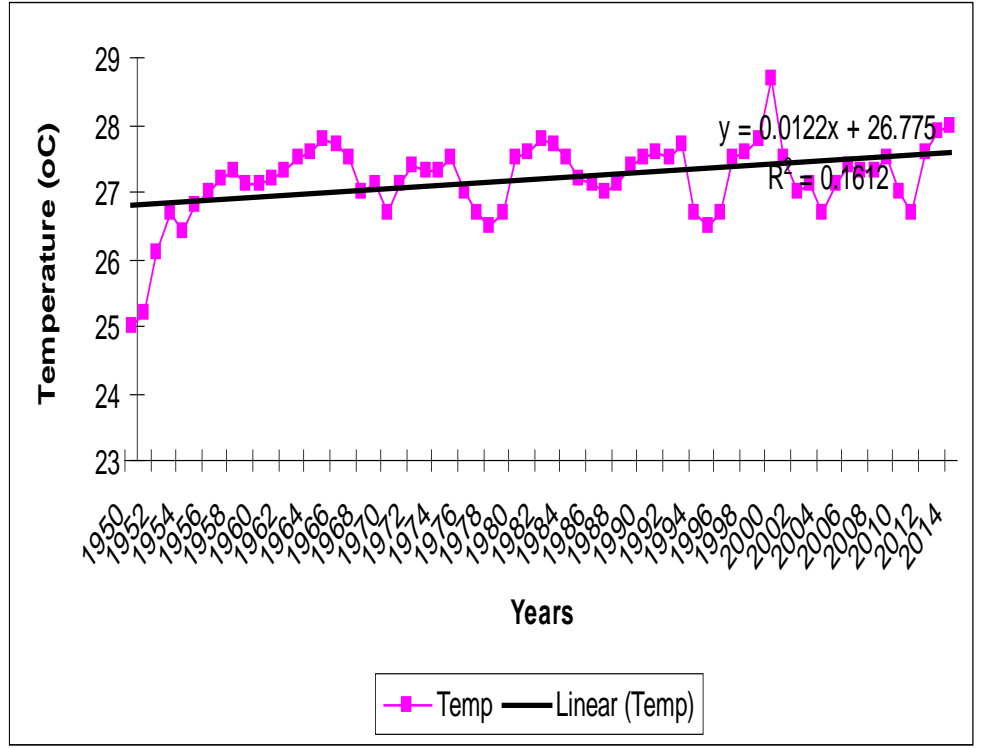

Figure 3. Mean annual distribution of temperature (1950-2014).

Table 1. Seasonal distribution of malaria cases and climate characteristics 1950-2012.

\begin{tabular}{ccccccccccccc}
\hline Months & Jan & Feb & Mar & Apr & May & Jun & Jul & Aug & Sept & Oct & Nov & Dec \\
\hline Malaria & 482 & 679 & 719 & 743 & 798 & 802 & 1006 & 553 & 1540 & 671 & 508 & 637 \\
Rainfall $(\mathrm{mm})$ & 28 & 64 & 130 & 174 & 255 & 273 & 359 & 306 & 368 & 268 & 100 & 30 \\
Temp ${ }^{\circ} \mathrm{C}$ & 27 & 27.4 & 28.6 & 28.3 & 27.6 & 26.8 & 26.1 & 26.2 & 26 & 26.7 & 27.1 & 27.2 \\
\hline
\end{tabular}

fall, and with polynomial trend $\mathrm{R}^{2}$ of 0.26 (see Figure 6). This is in congruence with the feature of tropical equatorial climate of Koppen [19].

Table 2 showed 0.805 correlation coefficient value between the criterion (malaria) and the predictor (rainfall and temperature), indicating $0.648 \mathrm{R}^{2}$ value which implies that rainfall and temperature had $65 \%$ influence on 


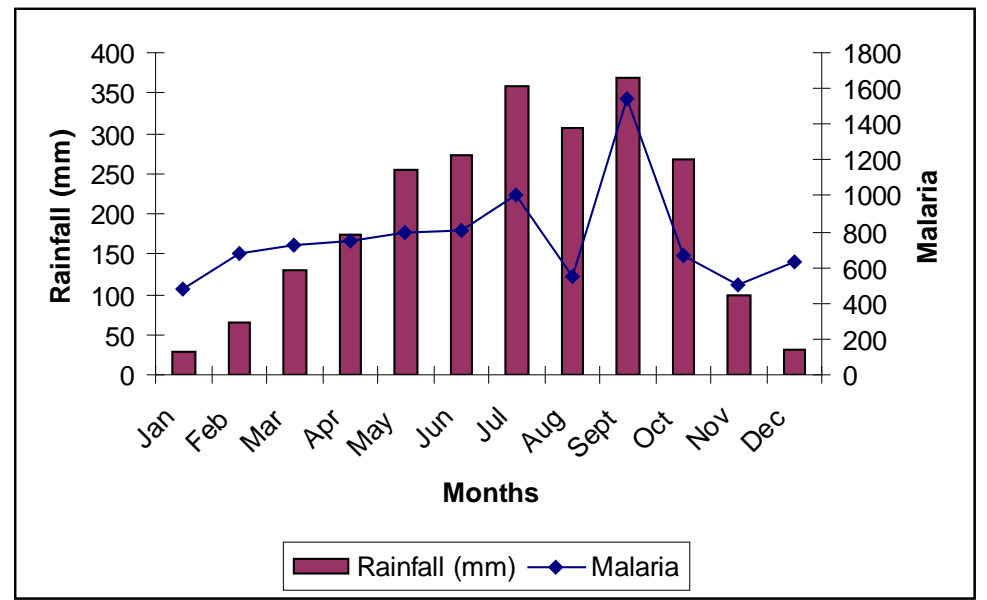

Figure 4. Monthly distribution of malaria and rainfall.

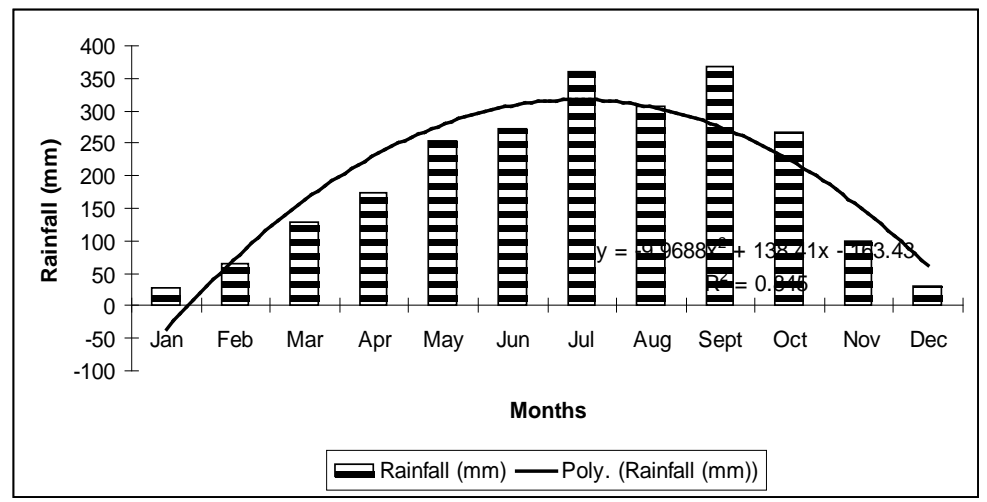

Figure 5. Monthly rainfall pattern.

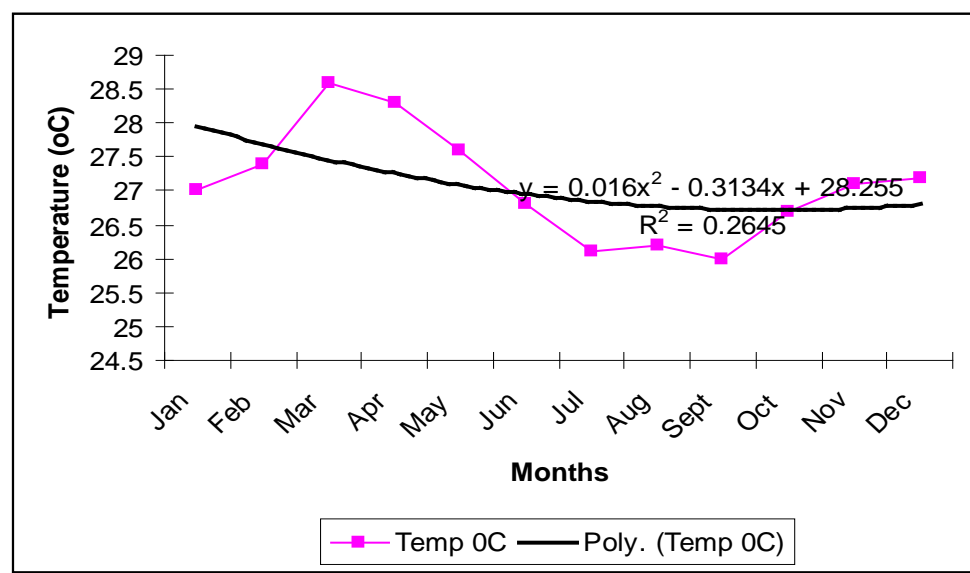

Figure 6. Monthly temperature pattern.

the prevalence of malaria in Port Harcourt, while the remaining 35\% is accounted for by housing, poor environmental condition, and population changes in the Port Harcourt city. However the Beta standardized coefficients showed rainfall had a strong positive correlation value of 0.765 , indicating that as rainfall increases, there is a corresponding increase in the cases of malaria reported in Port Harcourt. Temperature on the other had a strong negative correlation value of -0.600 (inverse relationship), which shows that cases malaria reported dur- 
Table 2. Standardized coefficients explaining the effects of rainfall and temperature on malaria cases.

\begin{tabular}{|c|c|c|c|c|c|c|c|}
\hline \multirow[t]{2}{*}{ Model } & & \multicolumn{2}{|c|}{ Unstandardized coefficients } & \multirow{2}{*}{$\begin{array}{c}\text { Standardized } \\
\text { coefficients } \\
\text { Beta }\end{array}$} & \multirow[t]{2}{*}{$\mathrm{r}$} & \multirow{2}{*}{$\begin{array}{l}\mathrm{T} \\
\mathrm{B}\end{array}$} & \multirow{2}{*}{$\begin{array}{c}\text { Sig. } \\
\text { Std. error }\end{array}$} \\
\hline & & B & Std. error & & & & \\
\hline \multirow[t]{3}{*}{1} & (Constant) & 1831259.339 & 322110.217 & & 0.805 & 5.685 & 0.000 \\
\hline & Rainfall & 122.402 & 160.271 & 0.765 & 0.765 & 0.764 & 0.448 \\
\hline & Temp & -67467.947 & 11847.443 & -0.600 & -0.600 & -5.695 & 0.000 \\
\hline
\end{tabular}

${ }^{\mathrm{a} D e p e n d e n t ~ v a r i a b l e: ~ M a l a r i a . ~}$

ing this period reduces with increases in temperature. This corroborated [6] [16]. In the wet seasons, mosquito's larvae development is at maxima due to the increase in precipitation and poor environment management [17]. Table 2 also showed that the calculated t value is 5.69 and it is significant at $\mathrm{p}<0.05$ significant level. Thus, the incidence of malaria in Port Harcourt is a significantly dependent on climate parameters (rainfall, and temperature).

\section{Conclusion}

The study revealed that there was $3^{\circ} \mathrm{C}$ rise in temperature, indicating an urban warming of $3^{\circ} \mathrm{C}$ from 1950 to 2014, and with $27.2^{\circ} \mathrm{C}$ mean temperature in Port Harcourt. Port Harcourt has $2375 \mathrm{~mm}$ mean annual rainfall, which recorded a wetter period of $1581 \mathrm{~mm}$ of rainfall from 1950 till date. The increase in rainfall and temperature consequently led to corresponding increase in the prevalence of malaria cases in Port Harcourt. Thus, an increase in rainfall and temperature enhances mosquito development and improved breeding sites leading to incidence of malaria. There are double rain maxima in July and September and double maxima of malaria cases with 1006 cases in July and 1540 cases in September. On this premise and health care planning and development, it is recommended that regular clearing of drains and the surrounding environment on monthly basis should be intensified most especially during the months of July and September when the rain is at its peak, as well as the distribution of mosquito's insecticide net by the three tier of government. Also the residents should embrace the various health programmes of reducing mosquitoes as specified in the local, state and federal government health polices.

\section{References}

[1] Molineaux, L., Muir, D.A., Spencer, H.C. and Werndorfer, H.C. (1988) The Epidemiology of Malaria and Its Measurement. In: Werndsdorfer, W.H. and Mcgregor, S., Eds., Malaria: Principles and Practices of Malariology, Churchill Livingstone, Philadelphia, 999-1089.

[2] Sharma, V.P. and Bos, R. (2003) Determinants of Malaria in South-Asia. In: Casman, E. and Dowlatabadi, H., Eds., The Contextual Determinants of Malaria, Resources for the Future, Carnegie Mellon University, Washington DC, 110132.

[3] Eisenberg, J.N., Desai, M.A., Levy, K., et al. (2007) Environmental Determinants of Infectious Disease: A Framework for Tracking Causal Links and Guiding Public Health Research. Environmental Health Perspectives, 115, 1216-1223. http://dx.doi.org/10.1289/ehp.9806

[4] Sutherst, R.W. (2004) Global Change and Human Vulnerability to Vector-Borne Diseases. Clinical Microbiology Reviews, 17, 136-173.

[5] Tsai, H. and Liu, T. (2008) Effect of Global Climate Change on Disease Epidemics and Social Instability around the World. An International Workshop on Human Security and Climate Change, Oslo, 21-23 June 2008, 21-23.

[6] Efe, S.I. and Ojoh, C. (2013) Climate Variability and Malaria Prevalence in Warri Metropolis. Atmospheric and climate Science, Scientific Research USA, 3, 132-140.

[7] Sachs, J. and Malaney, P. (2002) The Economic and Social Burden of Malaria. Nature, 415, 680-685. http://dx.doi.org/10.1038/415680a

[8] Whalther, G.R., Post, E., Convey, P., Menzel, A., Parmesan, C., Beebee, J.J.C., Fromentin, J.M., Hoegh-Guldberg, O. and Bairlein, F. (2002) Ecological Responses to Recent Climate Change. Nature, 416, 389-395. http://dx.doi.org/10.1038/416389a

[9] WHO (2004) Global Strategic Framework for Integrated Vector Management. WHO Document, WHO, Geneva, 1-12. 
[10] Chapman, C.A., Gillespie, T.R. and Goldberg, T.L. (2005) Primates and the Ecology of Their Infectious Disease: How Will Anthropogenic Change Affect Host Parasite Interactions? Evolutionary Anthropology, 14, 134-144. http://dx.doi.org/10.1002/evan.20068

[11] Mckenzie, V.J. and Townsend, A.R. (2007) Parasitic and Infectious Disease Responses to Changing Global Nutrient Cycles. EcoHealth, 4, 384-396.

[12] Ayoade, J.O. (2004) Climate Change: A Synopsis of Its Nature, Causes, Effects \& Management. Vantage Publishers Ltd., Ibadan.

[13] Alaba, A.O. (2005) Malaria and Rural Household Productivity in Oyo State. Ph.D. Thesis, University of Ibadan, Ibadan.

[14] WHO (2004) Action Plan for Malaria Control (1995-2000). Preventive Action and Intensification of the Struggle against Malaria Control, Mimeograph. World Health Organization, Geneva.

[15] Weli, V.E. and Worlu, S.O. (2011) Recent Rainstorm Dynamics and Its Implications for Flood Frequency in Sub-Humid Tropical City of Port Harcourt Nigeria. Journal of Geographic Thought, 12, 31-81.

[16] Eludoyin, O.S. and Weli, V.E. (2012) Spatial Analysis of Flood Vulnerability Levels in Port Harcourt Metropolis Using GIS. Journal of Earth Science and Engineering, 2, 617-623.

[17] Grover-Kopec, E.K., Blumenthal, M.B., Ceccato, P., Dinku, T., Omumbo, J.A. and Connor, S.J. (2006) Web-Based Climate Information Resources for Malaria Control in Africa. Malaria Journal, 5, 38.

[18] Vanwambeke, S.O., Lambin, E.F., Eichhorn, M.P., Flasse, S.P., Harbach, R.E., Oskam, L., et al. (2007) Impact of Land-Use Change on Dengue and Malaria in Northern Thailand. EcoHealth, 4, 37-51. http://dx.doi.org/10.1007/s10393-007-0085-5

[19] Efe, S.I. (2006) Regionalisation of Nigeria Climate: A Recent Approach. The Nigerian Academic Forum, 11, 32-39.

[20] Efe, S.I. and Ojoh, C.O. (2013) Spatial Distribution of Malaria in Warri Metropolis. Open Journal of Epidemiology, 3 , 118-124. 